\title{
A SOCIOLOGICAL APPROACH TO THE ADOLESCENT PREGNANCY IN THE LOW-INCOME POPULATION OF THE GRAN MENDOZA, ARGENTINA
}

AGUILO, Juan Carlos

Faculty of Political and Social Sciences, Universidad Nacional de Cuyo, Argentina.Correspondence to (jcaguilo65@gmail.com)

\section{COPYRIGHT NOTICE:}

(C) 2022 by author. Licensee ERUDITUS ${ }^{\circledR}$. This article is an open access article distributed under the terms and conditions of the Creative Commons Attribution (CC BY) license (https://creativecommons.org/licenses/by/4.0/).

\section{CITE THIS PAPER:}

Aguilo, Juan Carlos (2022). "A sociological approach to the adolescent pregnancy in the low-income population of the Gran Mendoza, Argentina" Journal of Social Sciences: Transformations \& Transitions (JOSSTT) 1(02):10. DOI:

https://doi.org/10.52459/josstt12100122

\section{ABSTRACT}

Our purpose is to contribute to the knowledge of the incidence of teenage pregnancy in the low-income sector of the Gran Mendoza by understanding them as part of their life strategies within the framework of their conditions of existence strongly impacted for low job opportunities and a reactive educational system. Pregnancy and motherhood in these adolescents are problematized considering that their incidence remains high compared to that for women of other social classes. We had chosen to know their opinions regarding their sexual and reproductive practices that drive them, or not, to the pregnancy and maternity. We think it is possible to argue that, in extreme conditions of social exclusion, with a lack of familiar support and limited cultural capital, teenagers tend to have sexual practices that drive them not to avoid pregnancies strongly influenced by traditional ideas regarding the role of women in society. On the contrary, when teenage women have bigger levels of cultural capital, dispute the reiterate tendencies of the traditional "class habitus" and report educational and professional life projects.

\section{KEYWORDS}

Teenage Motherhood, Habitus, Poverty, Social Policy, Argentina. 


\section{INTRODUCTION}

The objective of this paper is to share the main findings from our doctoral project named "A sociological contribution to the comprehension of adolescent pregnancy in the low-income population of the Gran Mendoza" developed from 2016 to 2020 at the Political and Social Sciences School in the Universidad Nacional de Cuyo, Mendoza, Argentina.

The theoretical and empirical approach to teenage pregnancies (and its consequent motherhood) in the low-income population from the Gran Mendoza has been made considering them as part of the adolescent life strategies in a context characterized by their deteriorated living conditions. In this paper, we are going to understand life strategies as the group of practices these women develop in their social environment originated from the class and gender habitus (Bourdieu, 1997, 2000, 2013). The age group is defined according to the indications of the World Health Organization (WHO), which considers adolescence the period going from 11 to 19 years, having two phases, early adolescence from 11 to 14 years and late adolescence from 15 to 19 years. This study focuses on pregnancy and motherhood in teenagers from the second group since it is relevant in numbers and because such phenomenon in girls who are younger than 14 years is considered abusive and under violent situations, exceeding the aim of our research (UNFPA, 2017).

The studies that analyze this problem confirm that the rates of teenage pregnancy's influence have kept its resistance to becoming low in the last decades in Argentina and Mendoza - like in Latin American countries $^{1}$ - despite the efforts done by public policies (Plan ENIA, 2019). These policies have tried, through sexual education and free distribution of different contraceptive methods, to diminish its impact on teenage women in the low-income population of our society (Binstock, 2016) (UNFPA, 2019). Last reports show that the figures are highly diverse among the social class and the different Argentinean provinces: for example, 12 of 24 provinces of the countries have figures above the average (13\% of the birth were from women below 19 years in 2018) but three provinces (Misiones, Chaco, and Formosa) presented figures that are almost double of the countries average (Plan ENIA, 2019) (Figures in Section 3 of this paper).

This unequal distribution of the phenomenon among the social class and the region of our country is one of the reasons which has encouraged our research because it holds our perception that these women condensate the most flagrant inequality from the capitalist and patriarchal society. Additionally, we wanted to verify if what is considered a "problem" from the normative point of view of medical and social recommendations is experienced and interpreted in the same way by the teenagers who go through this vital

\footnotetext{
1 “Although total fertility (number of children per woman) in Latin America and the Caribbean (LAC) has declined over the past 30 years, adolescent fertility rates have only dropped slightly during that period and continue to be the second highest in the world, surpassed only by those in sub-Saharan Africa". (PAHO/UNFPA/UNICEF, 2017: 13)
} 
experience. For this reason, and besides the importance of the quantitative data, we had chosen to analyze the phenomenon appealing to the qualitative methods using the semi-structured interview techniques (Section 2). In other words, we had followed Bourdieu's views: "In Bourdieu's eyes, the business of the sociologist is to denaturalize and to defatalize the social world, that is, to destroy the myths that cloak the exercise of power and the perpetuation of domination". (Wacquant, in Bourdieu and Wacquant, 1992: 50)

We want to anticipate that our conclusions coincide with the ones from the studies consulted, which expressed that, in the framework of the material conditions of existence characterized by deep economic and social deprivations, motherhood is considered by these teenagers as one of the few meaningful opportunities in their lives (Checa, 2003) (Gogna, 2005) (Pantelides and Binstock, 2007) (Molina, 2013) (Rodriguez Vignoli, et al., 2017). It is important to clarify that our approach is far away from a paternalistic or moral evaluation of these women, and we wanted to contribute to the understanding of their behaviors that conduct them to have a "no-expected" pregnancy (Rostagnol, 2016).

Throughout this research, we think that the subjective practices of the teenagers from the low-income population of our country should be understood in a context of the deep deterioration of their daily life due to the impact that the dislocation of the labor world had generated in the living conditions of the poorest population of Argentina after more than 30 years of the implementation of neoliberal accumulation model (Minujin, 1993) (Svampa, 2005) (Benza, 2016) (Piovani and Salvia, 2018). In this process, the most affected ones of the wide portion of Argentine society have been and even are the young sectors, who really suffer from the vulnerabilities of the labor precariousness (Salvia and Tuñón, 2006) (Calero, 2018) (Saavedra, 2018).

Apart from these characterizations, we believe that it is essential to tackle the aim of the study from a sociological perspective recovering the theoretical contributions of Pierre Bourdieu (1997, 2000, 2013) and its category of habitus to reveal our interpretations of the teenage practices and the extra contributions about the scope and implications of it done by Bernard Lahire (2005), Ana Teresa Martinez (2007), Lois Wacquant (2016) and Juan Dukuen (2018) among others. We have done this interpretation in constant dialogue with the contribution of the gender studies (Brown, 2006) to reach a deep understanding of the subordinate position of teenage women in the capitalist and patriarchal society.

Following these previous ideas, we believe our contribution is to demonstrate through the application of the habitus concept the key factors participating in the situation that conduct, or not, the adolescent girl to pregnancy and motherhood and, consequently, to provide insights to improve social policies in the area of sexual and reproductive rights. 


\section{METHODOLOGICAL PERSPECTIVE}

We think that in reaching our goal of cooperating with the understanding of teenage pregnancy and motherhood in low-income populations it is crucial to have as empirical information the interpretation and explanation expressed by the pregnant teenagers ${ }^{2}$. Consequently, and after analyzing the quantitative data available for the phenomenon, we had appealed to the qualitative methodology ${ }^{3}$ by making semi-structured interviews with adolescent women. In other words, the use of qualitative methodology is a logical consequence of the investigation objectives and its theoretical approach because it "is a form of social action that stresses on the way of people interpret and make sense of their experiences to understand the social reality of individuals" (Mohajan, 2018: 2).

Following the previous ideas, the selected cases have been determined based on the strategy of the purposive sampling from the criteria that teenagers (15 to 19 years) who were pregnant or became mothers, living in some of the departments of Gran Mendoza in poor and/or marginalization conditions. The number of interviews made has complied with the "saturation" criterion ${ }^{4}$ based on which we had continued to collect data until no relevant insights emerged from the interviews (Piovani, 2018). The interviews can be defined as "oriented interviews" in which we used a set of oriented questions for getting the adolescent opinion about their economic condition, school trajectories, sexual and reproductive activities (including anti conceptive methods knowledge), and their evaluation and vision about motherhood and maternity roles and responsibility. All the interviews were recorded with the authorization of the woman and were immediately transcribed in full. After two years of fieldwork, we interviewed 16 teenagers who were pregnant or became mothers and reside in poor households in different zones of Gran Mendoza: three adolescents of 16 years old, four of 17, five of 18, and four of 19. From this total number, two of them were pregnant at the interview moment; twelve were one-child mothers, and two of them were mothers of two children. From the 16 adolescent mothers only two of them had finished secondary school, the other had abandoned the school.

Additionally, we had made two focus groups with adolescent women coming from the same zones and economic conditions that were not pregnant or mother. In this case, we use the focus group techniques ${ }^{5}$ and

\footnotetext{
2 "Qualitative researchers are interested in people's belief, experience, and meaning systems from the perspective of the people". (Mohajan, 2018: 2)

3"It is a type of social science research that collects and works with non-numerical data that seeks to interpret meaning from these data that help us to understand social life through the study of targeted populations or places. It focuses on words rather than numbers, this type of research observes the world in its natural setting, interpreting situations to understand the meanings that people make from day-to-day life". (Mohajan, 2018: 2)

4 "Data collection is considered saturated when no new elements are found and the addition of new information ceases to be necessary, since it does not alter the comprehension of the researched phenomenon". (Nascimento et al, 2018: 228)

5 "As a qualitative method for gathering data, focus groups bring together several participants to discuss a topic of mutual interest to themselves and the researcher. Researchers can use the audio tapes and transcripts produced by focus groups either as a source of data in and of themselves or as an adjunct to other forms of data collection". (Morgan \& Spanish, 1984: 253)
} 
ten adolescents participated in two different discussions made during 2019. On the contrary to the previous group, all the women were schooled and many of them had expressed their wishes to continue studying in universities careers. The empirical material of this discussion was a key resource for understanding the meaning of being a mother for this adolescent in their particular conditions of life in comparison with the testimonies coming from the interview to the pregnant or mother adolescent.

After the analysis of the empirical material with the lens of our research hypothesis which has guided our interpretation process ${ }^{6}$, we can anticipate that motherhood tends to appear as one of the few vital projects for adolescents living in social hardship conditions. In other words, in more severe conditions of economic and social exclusion and low level of empowerment provided by the cultural capital ${ }^{7}$, motherhood tends to become one of the few alternatives appearing on the horizon of possibilities of these adolescents. At the same time, they show a high grade of adhesion to the traditional discourses which reproduce stereotypes for their gender, considering motherhood, and the tasks it involves, as "natural" attributes for women. Therefore, they consider that childcare is their entire responsibility, and the child could be filling an existential gap in the framework of living conditions highly deteriorated. The "misfortune" or "unexpected" words used by our interviews for qualifying the pregnancy can give us the clue that many of them are far away from any kind of decisive processes to face the asymmetric sexual situation with their male partner in the patriarchal context of their life in which being mothers could be function also as recognition from its peers ("social/symbolic capital") ${ }^{8}$ and giving sense to their lives. In an oppositive way, those adolescents with the highest level of cultural capital - in terms of larger years of school attendance and a greater level of knowledge about sexual and reproductive health - were/are in better condition to dispute "the unavoidable motherhood destiny" . by developing labor and/or education personal projects. We are going to deep these interpretations in section 5 of this work after presenting in section 3 a short characterization of the adolescent living condition in Argentina and section 4 makes a presentation of the statistic and figure that shows the incidence of adolescent motherhood in Argentina and Mendoza.

\footnotetext{
6 "Bourdieu maintains that every act of research is simultaneously empirical (it confronts the world of observable phenomena) and theoretical (it necessarily engages hypotheses about the underlying structure of relations that observations are designed to capture)". (Wacquant, in Bourdieu and Wacquant, 1992: 35)

7 "I have analyzed the peculiarity of cultural capital, which we should in fact call informational capital to give the notion its full generality, and which itself exists in three forms, embodied, objectified, or institutionalized". (Bourdieu, in Bourdieu and Wacquant, 1992: 119)

8 "Social capital is the sum of the resources, actual or virtual, that accrue to an individual or a group by virtue of possessing a durable network of more or less institutionalized relationships of mutual acquaintance and recognition" (Bourdieu in Bourdieu and Wacquant, 1992: 119).

9 "The internalization of objective chances in the form of subjective hopes and mental schemata plays a key role in Bourdieu's analysis of social strategies, whether it be in schools, in labor and marriage markets, in science, or in politics" (quote 84 in Bourdieu and Wacquant, 1992: 130).
} 


\section{URBAN TEENAGERS AND YOUNG PEOPLE FROM LOW-INCOME POPULATIONS}

\subsection{Demographic situation and living conditions of teenagers and young people}

In terms of demographic settings, Argentina and Mendoza share the general processes which have happened in Latin America during the 20th century: a course of intense urbanization based on the rural-urban migratory movements to the interior of the countries, life expectancy increase, and fertility decrease leading to a general process of population aging and the standstill of child and teenage population (Binstock and Cerruti, 2016) (Kessler, 2016).

In addition, recent studies (Benza, 2016) (Piovani y Salvia, 2018) confirm the observations on the Argentine social structure which, since the middle of the eighties (Minujin, 1993) started to verify an impoverishment process of the working and middle-class population as the other side of a wealth concentration generating higher levels of heterogeneous conditions and inequality in the Argentine society. These processes lead to this scenery of social exclusion, known as "pulverization of social scenery" (Tenti Fanfani, 1993), and mainly affected teenagers and young people inside the popular sector. Higher unemployment rates, precarious conditions in the labor market, and low school attendances rates characterized the situation of teenagers and young people from low-income populations. (Salvia and Tuñón, 2006) (Svampa, 2005). In other words, the unemployment or informal labor situation ${ }^{10}$; the high drop-out rate; the difficulties of access to public health services, and their lives existences in relegated housing had characterized the living condition of a greater sector of young and teenager population in Argentina at the beginning of the XXI century (Tuñón, 2018).

Although there was an improvement in labor and salary conditions during the 2003-2015 period and the recovering of the regulatory role of the State took place, the inequity seen in unemployment rates and the scarcity conditions presented in youth sectors in comparison to other age groups could not be reverted (Calero, 2018) (Saavedra, 2018). In conclusion, the accomplishments from the 2003-2015 period did not achieve to modify the structural economic and social tendencies that modify the Argentinean since the middle of the seventies and conduct to a more unequal, fragmented, and polarized society (Pérez y Busso, 2018) (Piovani y Salvia, 2018). Additionally, and as we had mentioned before, being an adolescent woman from the low-income sectors would imply high probabilities of vulnerable and stagnant lives.

\subsection{Exclusion conditions and subjectivities}

It is important to relate the previous description with the approach that discuss the effects of the destruction of the social framework - abovementioned - in the popular subjectivities. We speak about popular

\footnotetext{
${ }^{10}$ The unemployment rate for 15 to 24 ages increased from 13\% in 1991 to 33\% in 2002 (Salvia \& Tuñón, 2006)
} 
subjectivities being away from old philosophical discussions about the ontological status of the person and the "enchanted" visions about himself. We understand the "subjectivity" based on the conceptualization of Bordieu (1997, 2000, 2013) as the concrete setting of people's practices ("strategies") from the habitus the carries.

Bourdieu is at pains to emphasize that his economy of practice is either internationalist or utilitarian. As argued above, he is staunchly opposed to the finalism of philosophies of consciousness that situate the mainspring of action in the voluntaristic choices of individuals. By strategy, he refers not to the purposive and preplanned pursuit of calculated goals, but to the active deployment of objectively oriented "lines of action" that obey regularities and form coherent and socially intelligible patterns, even though they do not follow conscious rules or aim at the premeditated goals posited by a strategist. (Wacquant, in Bourdieu and Wacquant, 1992: 25)

Withdrawn in deteriorated territories (Merklen, 2010) and homes awkwardly constituted; targeted by focused and conditional social policies; weakly inserted on an education system; and precarious inserted in the labor market; our teenage girls spread out their subjective practices, showing high vulnerability to life risks and unexpectedness trying to find "reference anchors" (Duschatzky \& Corea, 2009: 74) which could give sense to their precarious lives. From a Bourdieu perspective the "anchor" means that motherhood could appear as the condition that provides certain kinds of social status, or more specific, a "symbolic capital" in highly precarious and fragile life trajectories. In other words, motherhood could be thought of as the material and the symbolic situation reached by the repetition of the non-reflexed sexual practices by the adolescent.

\subsection{Public Policies in Sexual Reproduction in Argentina and the incidence of adolescent} pregnancy

Although there are laws and programs given in the last decade, especially the Law of Comprehensive Children and Teenagers Protection (Ley de Protección Integral de Niñas, Niños y Adolescentes) (26061/2015), Argentina shows high rates of teenager's fertility despite their economic development level according to the region (Pantelides \& Binstock, 2007) (Binstock, 2016) (UNFPA, 2017). In other words, despite the efforts made by the public policies, the incidence of adolescent pregnancy shows an unequal distribution among the different regions of the countries and social classes. For the lower-income class and in some provinces of the country, the figures are quite similar to the ones for Latin American countries.

Despite recent economic growth and social progress on a number of fronts in Latin America and the Caribbean (LAC), adolescent fertility rates remain unacceptably high, the second-highest in the world, with major inequities between and within countries. Girls from families in the lower wealth quintile, 
with lower levels of education, and from Indigenous and Afro-descendant communities are disproportionately affected by adolescent pregnancy. (PAHO/UNPFA/UNICEF, 2016: 9)

The previous sentences can be observed in the following Graph 1, made by the authors based on Rodriguez Vignoli et al. CEPAL, 2017.

Graph 1: Global Fertility Rate \& Adolescent Fertility Rate by world region. 2010-2011

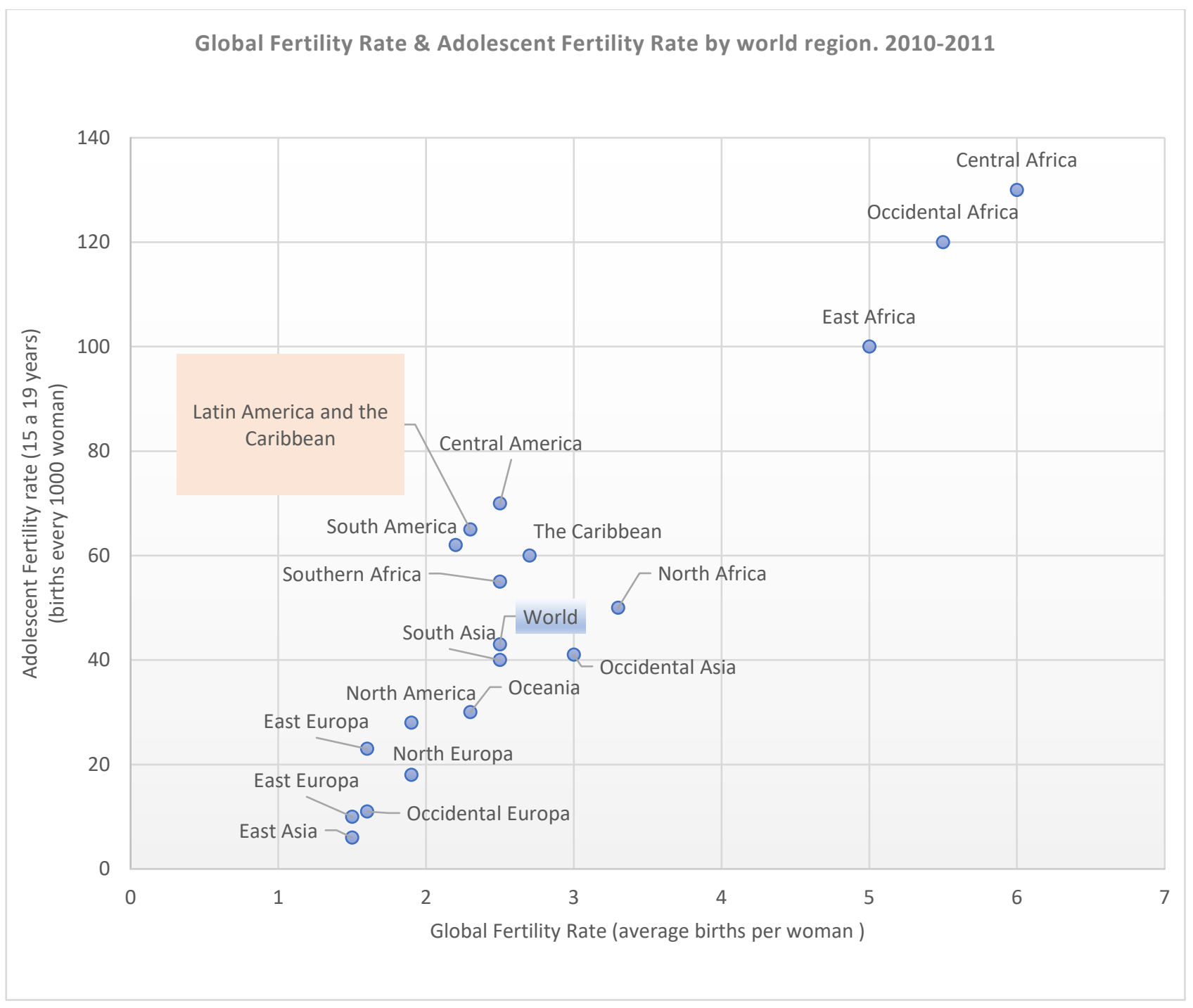

Though in Argentina and Mendoza it is possible to observe, on average, figures less worried than the ones from Latin American countries, the unequal distribution among social classes and the disparities among different provinces show the unfair phenomenon incidence as can be observed in Graph 2, elaborated based on the data from UNICEF/MSDS (2019). 
Graph 2: Percentage of the childbirth from adolescent mother by province (Argentina, 2018)

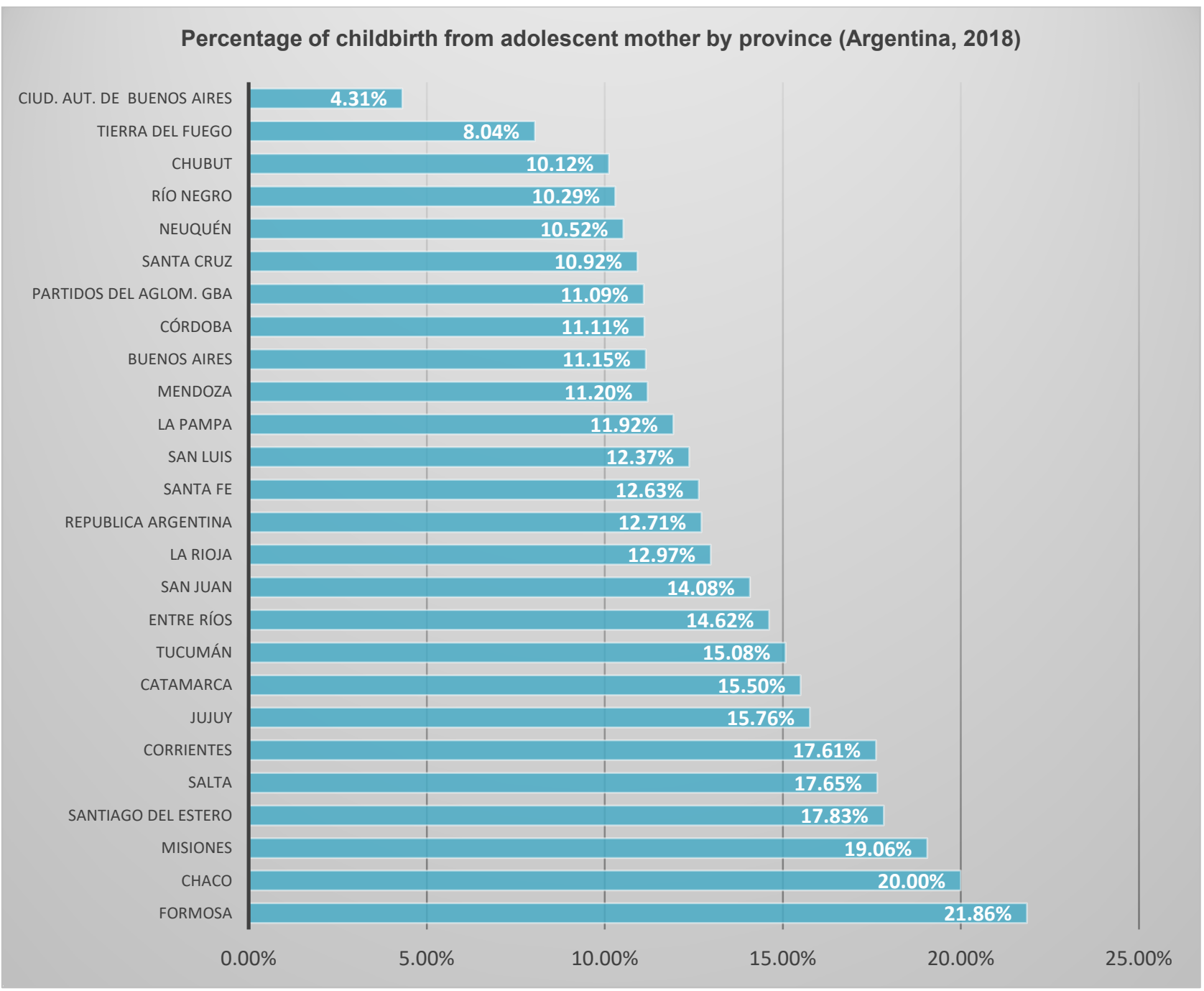

This unfair regional distribution has been one of the fundaments for launching from different ministers in 2017 the National Plan for the Prevention of Non-intentional Adolescent Pregnancy (Plan ENIA). Besides these previous reasons the Plan ENIA sustains its interventions in the fact that the majority of this adolescent pregnant comes from women living in the poorest households of the country for which we can apply the following quote elaborated for Latin American countries.

Adolescent pregnancy profoundly affects girls' life trajectories. It hampers their psychosocial development, contributes to poor health outcomes for the girls and their offspring, negatively affects their educational and employment opportunities, and contributes to the perpetuation of intergenerational cycles of poor health and poverty. (PAHO/UNPFA/UNICEF, 2016: 9) 
Even though the Mendoza figures for the phenomenon are closed to the country average and not so high as the ones for the provinces in the north of Argentina, we think the following numbers for Mendoza are a clear manifestation of an unequal and unfair situation for adolescents in the poorest sector of our population. Graph 3, elaborated based on the data from UNICEF/MSDS (2019) shows the live births according to the mother's age.

Graph 3: Live births according to the mother's age. Mendoza, Argentina, 2017

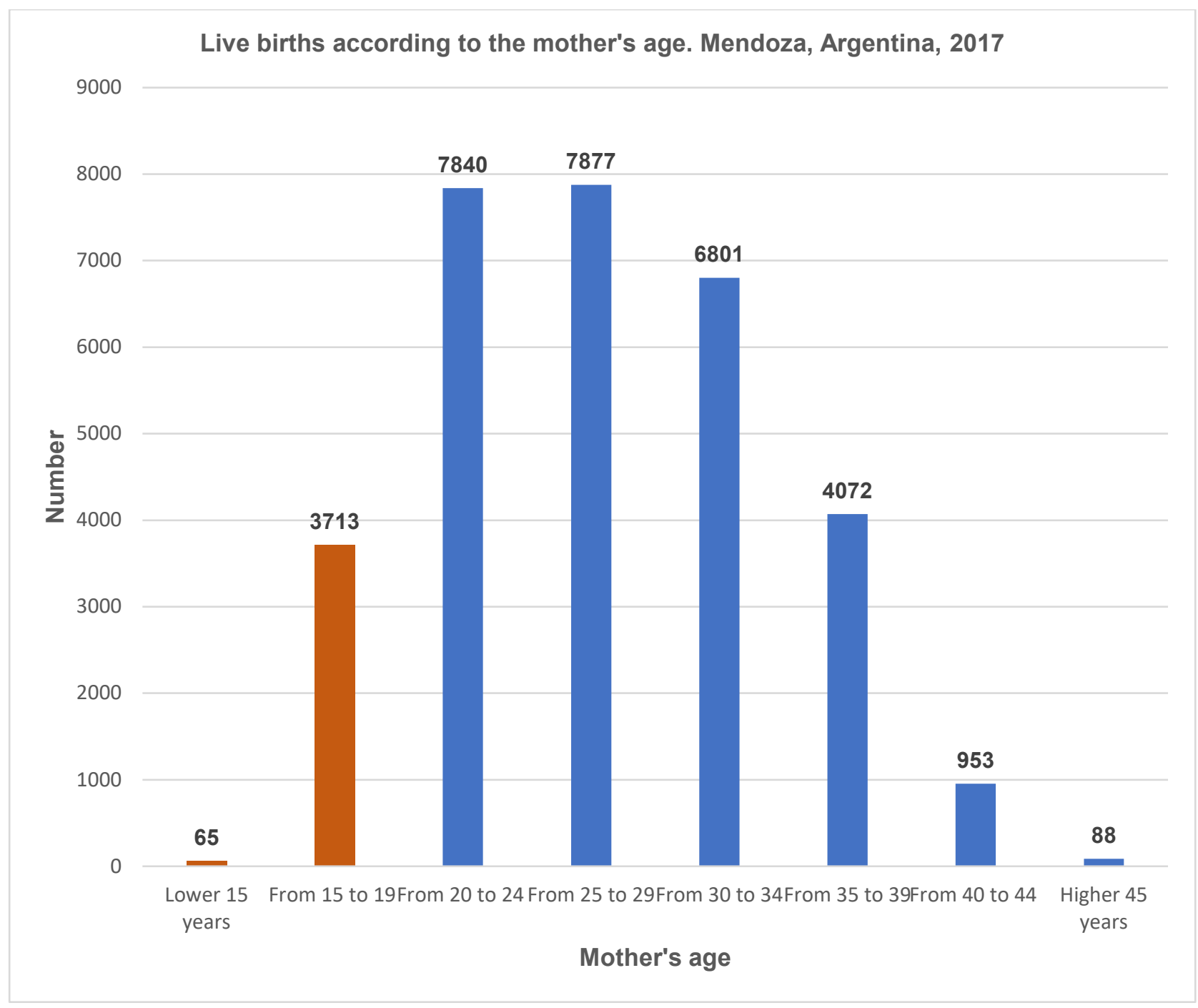

As we had mentioned, these figures are the strong evidence for a phenomenon that condensate the class and gender inequality that called us to a sociological tackle in which we have tried to get the words from the woman behind these numbers and to show "the somatization of social relations of domination". (Wacquant, in Bourdieu and Wacquant, 1992: 24) 


\section{DISCUSSIONS REGARDING HABITUS CATEGORY AND ITS CONTRIBUTION TO} THE EXPLANATION OF THE TEENAGE PREGNANCY PHENOMENA

Far away from the "imaginary anthropology of the subjectivity" from the rational action theory ${ }^{11}$ (Bourdieu, in Bourdieu and Wacquant, 1992: 123), Bourdieu understands the dialectic between structure and subject from the habitus category,

designed to transcend the opposition between objectivism and subjectivism. In his hands, habitus is a mediating construct that helps us revoke the common-sense duality between the individual and the social by capturing 'the internalization of externality and the externalization of internality', that is, the ways in which the sociosymbolic structures of society become deposited inside persons in the form of lasting dispositions, or trained capacities and patterned propensities to think, feel and act in determinate ways, which in turn guide them in their creative responses to the constraints and solicitations of their extant milieu. (Wacquant, 2016: 65)

Or, in other words, habitus is the generating principle of "strategies which allows the agents to face unexpected and always changing situations (...) a system of durable and transferable regulations that, integrating past experiences, works always with a matrix of perceptions, appreciations, and actions which make the task making indefinitely diversified". (Wacquant, in Bourdieu \& Wacquant, 1992: 18)

We believe that this idea of habitus allows us to understand and capture the subjective practices narrated by our interviewees which lead them to, in certain conditions, repeat family stories regarding pregnancy at an early age as it is possible to see in the following testimony.

\section{Do you always picture yourself as a mother?}

Well...I was always paying attention to my siblings, I have six siblings, I am the eldest...I gave a bath to my siblings, I cooked for them, I did everything for them, I imagined them as my own children ...even today, if I have to change them, I do it, I do the same with her, I was already burly to become a mother... (Evelyn, 18)

\footnotetext{
11“"This narrow, economistic conception of the "rationality" of practices ignores the individual and collective history of agents through which the structures of preference that inhabit them are constituted in a complex temporal dialectic with the objective structures that produced them and which they tend to reproduce". (Bourdieu, in Bourdieu and Wacquant, 1992: 123)
} 
The explanation given by Bourdieu is not limited to presenting the habitus as a social practices generator, but as a generator of the interpretations about them. "Acquired system of generative schemes, the habitus makes possible the production of free thoughts, every perception and every action registered in the inherent limits to the particular conditions of its production and, only of them" (Bourdieu, 2013, 89) Or, in other words, "the theory of habitus acknowledges that agents actively make the social world by engaging embodied instruments of cognitive construction; but it also insists, against constructivism, that these instruments are themselves made by the social world through the somatization of social relations". (Wacquant, 2016: 67)

\section{And apart from your experience with your siblings, did you imagine how it was to experience pregnancy?}

No, because taking care of her (referred to her daughter) is quite different from having her inside you...it is something more...I was pregnant and I loved the way she moved, when she kicked, when I grabbed her in my arms, when I saw her next to me...since that moment I imagined a different life, a different story for me, I was completely changed because I was always hanging out with my friends and thank God that since she was born, I change a lot... (Evelyn, 18)

We understand that the habitus category provides a theoretical tool ${ }^{12}$ to comprehend the repetitive sexual practices which lead teenagers to allow (do not avoid) pregnancy because let to explain the correspondence between their life strategies and their social structure (highly deprived material means of living). In other words, the objective social conditions which produce the individual habitus of our interviewees have not varied throughout their short life, so, this continues operating in a practical way in the world that they are supposed to live. "Habitus operates as the 'unchosen principle of all choices' guiding practices that assume the systematic character of strategies even though they are not the result of strategic intention and are objectively 'orchestrated without being the product of the organizing activity of a conductor'. (Bourdieu, 1980a: 256 in Waquant, 2016: 67) This consideration is valid when, additionally, neither the material conditions nor the patriarchal stereotypes have modified these sectors regarding the roles of men and women that we are able to observe in the narrations presented.

12 "Habitus puts at the heart of social analysis the genetic mode of thinking as it directs us to excavate the implicit cognitive, conative and emotive constructs through which persons navigate social space and animate their lived world" (Wacquant, 2016, p. 70). 
Additionally, we consider that Bourdieu's contributions are key to see the misfortune in which the interviewees express that considering pregnancy as something that just "comes" or "happens" and, what's more, pregnancy turns into the only way of giving sense to their lives in these exclusion conditions ("the particular universe of probabilities"). Ultimately, the "probable future" for these teenagers has been reduced to their mother's conditions. In other words, the material conditions of high economic and social deprivation existing in our society, teenagers present a class habitus in which they do not avoid pregnancy as a way of giving sense to their lives and finding recognition from their social surroundings.

At the same time and due to the habitus "is enduring but not static or eternal: dispositions are socially mounted and can be eroded, countered or even dismantled by exposure to novel external forces, as demonstrated by situations of migration and specialized training" (Wacquant, 2016: 66) the concept let us explain the symbolic and materials practices ("strategies") of the adolescent that avoided to become pregnant because of a specific combination of cultural capital and household characteristics and concrete these practices in their interpersonal relationship with their couples. We are going to see these testimonies further in this paper.

\section{MISFORTUNE OR CHOICE? THE PLACE PREGNANCY AND MOTHERHOOD HAVE IN TEENAGERS' CONCEPTIONS OF THE LOW-INCOME POPULATION OF GRAN MENDOZA}

The interviewed teenagers are clear representative of those populations of peripheral and degraded neighbors of Gran Mendoza, hardly linked to the labor market, weakly inserted in the education system, and very vulnerable to the macroeconomic volatile conditions. In other words, subjectivities undoubtedly represent the ones more affected by the impact of the labor market and social protection deterioration and reduction. (Merklen, 2010)

Besides comprehending the specific social and economic conditions that affect the live condition of the adolescent in our research we are aware that, because of its relational characteristics, adolescence means different practical and symbolic experiences among the social classes. (Margulis, 2003) In addition and in concordance with the previous statement, we understand gender as a cultural and social construction that allows knowing that the dominant vision about masculinity and femininity presents variabilities among the

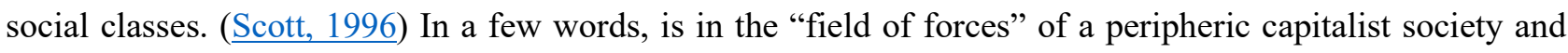
particular condition of patriarchal hegemony values where the interview adolescents develop their symbolic and practical life strategies. 
In the framework of this previous characterization, when asked about pregnancy causes, most of the interviewees say that pregnancy was something that happened, clearly, it is not planned, being consistent with the findings and conclusions from the most relevant studies of this topic in Argentina and Latin America (Checa, 2003) (Gogna, 2005) (Amorin et al., 2006) (Pantelides and Binstock, 2007) (Mansione et al. 2012) (Molina, 2013) (Rodriguez Vignoli et al., 2017)

\section{No, I was not waiting for it, it happened, it happened...it was not a bad moment because it was not ...but it happened without looking for it (Débora, 19)}

No, I did not want it at that moment, but yes...taking care of her does not bother me, it has not modified a lot the time, but I take her with me, everywhere I go, I shop, I take her, I go to school, I take her... (Stefania, 16)

These testimonies reflect a kind of "misfortune" widely described in the abovementioned studies when these pregnancies take place. At the same time, this "arrival" of the unexpected (pregnancy) is presented in the narrations and interpretations with the statement that there is no lack of awareness of the contraceptive methods but a problem of nor systematic employ of them. Although we agree with the interpretation that this erratic or inconsistent use of contraceptives methods could be related to the "relative disrespectful treatment towards their own body" that adolescents could present (Margulis, et. al., 2003: 206), we sustain that the apparent incongruence between a high degree of knowledge and low level of contraceptives methods utilization can be explained applying the habitus category.

As the numerous studies show and we could find in our field research, in the framework of traditional values of gender present in the low income's population motherhood is working as a way of self-assertion, a "vital anchor" that may be interpreted as a "symbolic capital". (Bourdieu, 2013) The teenager, now pregnant or mother, is somebody important who deserves care and respect, and her self-esteem and self-evaluation are inextricably related to her children's. So, becoming a mother gives a symbolic place where respect, acknowledgment, and visibility from others are placed." (Mansione et al., 2012: 138) In other words, "children, in a context of scarcity, give certain social prestige, identity and a feeling of possession of something created by themselves. Children become something possible and wanted." (Mancini and Wang, 2003: 236) 
Yes, I was never at home before, and now I am, I am with her all the time...I went out with friends, we hung out and this does not happen anymore, there are things during winter that I can't do because it's cold and sometimes to go out...well, at least...my mother made my bed, she tidied everything up and the father after seeing the results...he came, he came, he was present. I did not go out with her for a month because she was very little and...but it was correct to do it... (Stefania, 16)

Regarding the ideas and values related to the role of women at home and motherhood, in particular, the narrations show traditional visions for the almost exclusive responsibility of the mother when taking care of their children and doing house chores. This responsibility which is almost exclusive shows a certain balance with motherhood giving them social status, it is a way to find a "place in the world". The life project of becoming a mother to reach this condition in their lifecycle as early as possible will give her this place in her social reality with added value which gives sense to her life. Motherhood is "being someone". The child may represent part of the capital according to the place he socially has in the family. In that sense, for some people, it means "to have" something, which represents "to be somebody" and for that reason, the child strengthens identity, a constitutive part of the subjectivity. Some teenagers feel it strengthens their self-representation as women. We can appeal to the Bourdieu category of "symbolic power" to understand this kind of recognition these adolescents have in their motherhood role.

Symbolic capital also captures Bourdieu's notion that power is never so efficient (and dangerous) as when it disguises itself and gets paradoxically activated by the subordinate so that it proceeds via a cognitive relationship of assent opaque to itself obviating the expenditure of material suasion. Symbolic violence is that effortless force that molds the world via communication without us even noticing it; it tricks dominant and dominated alike, as in Masculine domination (Bourdieu, 2001 [1998], in Waquant \& Akçaoğlu, 2017: 57).

We have said that habitus allows us to explain this tendency to repeat symbolic and practical behaviors that conduct adolescents not to avoid becoming pregnant in a kind of "vicious circle of poverty" because their gender and class habitus,

is endowed with built-in inertia, insofar as habitus tends to produce practices patterned after the social structures that generated them, and because each of its layers operates as a prism through which later experiences are filtered and subsequent strata of dispositions overlaid (thus the disproportionate weight of the schemata implanted in infancy, among which the binary opposition between masculine and feminine. (Wacquant, 2016: 
But, at the same time, due to habitus "is enduring but not static or eternal: dispositions are socially mounted and can be eroded, countered or even dismantled by exposure to novel external forces, as demonstrated by situations of migration and specialized training" (Ibidem: 66) also allow us to understand the practical example of adolescent women coming from the same social class that avoids becoming pregnant. In other words, a not mechanical application of habitus concept - that could move us to believe that all the poor adolescents are going to become a mother in a context of deprivation - let to understand and explain the many cases of poor adolescents that can dispute and challenge the motherhood destiny.

We could find examples of this social and personal dispute in the evidence coming from the adolescents that participate in two different focus groups of discussion. Certainly, among a diverse scope of valorization about pregnancy and motherhood, these testimonies express - from the extreme position of not having motherhood as a life project to the ones that consider maternity as one among many alternatives' future projects for women - the various range of "empowerment" they present and let them question and confront the hegemonic patriarchal values.

I have the idea to become an entrepreneur soon. I had studied stylist and make-up and I want to have my own business and to achieve my personal and professional fulfillment based on knowledge. I do not want to be a mother right now, maybe in the future after reaching my professional goals... (Lucia, 19)

I do not have the need to become a mother. I mean, for my future, I am focused on my professional and academic career, in getting a good job and travel... (Agustina, 18)

We have chosen two testimonies that represent the various express for the adolescent women participating in the group of discussion. We believe it is possible to examine that, although coming from similar economic and social conditions, the class habitus has been eroded (Dukuen, 2015) for values and knowledge that let the adolescent dispute the "exclusive maternity horizon" that we could observe in the discourse of the pregnant or mother adolescent.

Regarding our idea of empowerment, we understand this concept as the increasing of the selfassertiveness and confidence they need to have to "put in action" in the intimacy and unrepeatable sexual encounter in which they have to request to their couple the use of prophylactic. Many of the studies we had consulted based in the research field coming not only from Argentina but also from other Latin American 
countries pointed out that this personal and intimate act "condensates" the social structure (in terms of class and patriarchal force camp) that constraint the low-income adolescent women. In other words, and as we could get from our testimonies, the teenage women have to negotiate with her couple male the use of prophylactic in an intimate situation that, in many cases, is conditioned by romantic value. For standing and disputing against stereotype, as we could see in the testimonies, the adolescent woman has to use "a practical competency, acquired in and for action, that operates beneath the level of consciousness and is continually honed in the very movement of its deployment". (Wacquant, 2016: 66)

Regarding this previous statement, we could observe and confirm that the increase of confidence that adolescent women have to deploy in the intimate act by demanding the use of condoms if they do not want to become pregnant is strongly related to their particular history of family support and, especially, for the grade of concrete knowledge they have regarding anticonception methods. In this case, we appeal to Bourdieu's concept of cultural capital (as one of the three spices of capital point by Bourdieu) to help us to understand that a strong basement of sexual and reproductive right knowledge clearly contribute to the improvement of this confidence ("cultural capital").

Two key variables, among others, participate in this improvement of confidence mentioned above: on the one hand, the free disposition of contraceptive methods in the public health system cannot be obstructed by the personal values of public officials (doctors and nurses). As we could obtain from the testimonies, in many cases adolescents find an "institutional barrier" in the public health system when they asked for the contraceptive method (that is free by law in Argentina) ${ }^{13}$. On the other hand, the intensity and quality of the application and development of sexual education (also established by law in Argentina) in secondary school is diffuse and irregular. As we could also get, some adolescents had a good evaluation of their professor and instructor regarding this issue while others complained about the lack of discussion and training about sexual reproductive rights. These two problematic and dissimilar situations show us the lines for improvement in the concrete implementation of the social policies. On the one hand, by eliminating the barriers in the public health system in relation to the free accessibility of contraceptive methods for adolescents and young people; and, on the other, by consistent instrumentation of the National Law of Sexual Education in the educational system.

After analyzing the testimonies from our field research with the Bourdieu framework, especially with the habitus category: "habitus puts at the heart of social analysis the genetic mode of thinking as it directs us to excavate the implicit cognitive, conative and emotive constructs through which persons navigate social space and animate their lived world" (Wacquant, 2016: 70), we strongly believe that a constant and coherent implementation of Sexual Reproductive Right policies from the educational and health public system can

\footnotetext{
${ }^{13}$ Argentinean Law 25.673/02.
} 
contribute to the increasing the adolescent cultural capital that we think is crucial to empower them in the order they can dispute -in a contra pedagogic way ${ }^{14}$ - the repetitive aspects of their habitus ${ }^{15}$ that let them avoid to become pregnant and develop alternative projects.

\section{CONCLUSION}

Through the narrations of adolescent mothers from the low-income population living in Gran Mendoza, we have tried to analyze the teenager pregnancy and motherhood phenomenon from our sociological view. In addition, and for a better understanding we listen to the explanation of non-pregnant/non-mother teenagers coming from the same social sector. By using a theoretical framework the main categories of Pierre Bourdieu and based on a qualitative methodology to get the adolescent speech we think we had confirmed for our targeted population the similar conclusion to the ones that had been reached in the most relevant and recognized studies of this field.

Under conditions of deep material, social and cultural scarcity, teenagers from low-income populations tend not to avoid becoming pregnant, not to pay much attention to the recommendations of reproductive health policies, and reproduce transgenerational inertia for their "destiny" as mothers and women. Showing contradictions and tensions, this gender and class misfortune leads them to repeat practices to allow pregnancy during their teenage period, even though they are aware of the contraceptive methods. We believe that habitus category allows us to understand this tendency to repetition but, at the same time, the opportunities to confront and overcame their subordinate position as poor women in a patriarchal and capitalist society. Indeed, we could find that those adolescent women with a high and strong level of knowledge of contra conception methods have the capacity to dispute this conservative "destiny" by developing labor and academic projects. While there are no structural changes made by the economic and social policy to modify the conditions towards an equitable structure of education and labor opportunities for teenagers in low-income populations, it is predictable to find the incidence of teenage pregnancy is at a high level despite the efforts made by public policies.

\footnotetext{
14 "Between the primary habitus, acquired in early childhood through osmosis in the familial microcosm and its extensions, and the secondary habitus, grafted later onto the latter by the specialized pedagogical labour of the school and other didactic institutions (a boxing gym, a painter's studio, a religious sect, a political party, etc.). The result is a compromise formation that dynamically articulates generic and specific dispositions across the life cycle into an operative set of schemata" (Wacquant, 2016: 69).

15 “'That habitus can 'misfire' and have 'critical moments of perplexity and discrepancy' when it is incapable of generating practices conforming to the milieu constitutes a major spring of personal resistance, social innovation and structural transformation" (Bourdieu, 1997: 191, in Wacquant, 2016: 69)
} 
FUNDING: The author did not receive any external funding.

CONFLICT OF INTEREST: The author declares no conflict of interest.

\section{REFERENCES}

1. David Amorín; Elina Carril; Carmen Varela (2006). Significados de maternidad y paternidad en adolescentes de estratos bajos y medios de Montevideo. In A. López Gómez (Coord.). Proyecto género y generaciones. Reproducción biológica y social de la población uruguaya. United Nations Population Fund (UNFPA). Available at:

https://www.academia.edu/373819/G\%C3\%A9nero_y_generaciones_Reproducci\%C3\%B3n_biol\%C3\%B 3gica_y_social de la_poblaci\%C3\%B3n_uruguaya_Estudios cualitativos

2. Benza, G. (2016). La estructura de clases argentina durante la década 2003-2013. In G. Kessler (Comp.) La sociedad Argentina hoy. Radiografía de una nueva estructura, Siglo XXI Editores. ISBN: 978-987629-626-7

3. Binstock, G. (2016). Fecundidad y maternidad adolescente en el Cono Sur: Apuntes para la construcción de una agenda común. United Nations Population Fund (UNFPA). Available at:

https://argentina.unfpa.org/es/publications/fecundidad-y-maternidad-adolescente-en-el-cono-sur-apuntespara-la-construcci\%C3\%B3n-de-una

4. Binstock \& Cerruti (2016). La población y la estructura social. In G. Kessler (Comp.) La sociedad Argentina hoy. Radiografía de una nueva estructura. Siglo XXI Editores. ISBN: 978-987-629-626-7

5. Bourdieu, P. (1997). Razones prácticas. Sobre la teoría de la acción. Anagrama. Available at: http://epistemh.pbworks.com/f/9.+Bourdieu+Razones+Pr\%C3\%A1cticas.pdf

6. Bourdieu, P. (2000). La dominación masculina. Anagrama. Available at: http://www.nomasviolenciacontramujeres.cl/wp-content/uploads/2015/09/Bondiu-Pierre-la-dominacionmasculina.pdf

7. Bourdieu, P. (2013). El sentido práctico. Siglo XXI Editores. Available at: https://sociologiaycultura.files.wordpress.com/2014/02/bourdieu-el-sentido-prc3alctico.pdf

8. Bourdieu, P. \& L. Wacquant (1992). An invitation to reflexive sociology. Polity Press in association with Blackwell Publishers. The University of Chicago. Cambridge, UK. Available at: http://www.sscnet.ucla.edu/polisci/faculty/chwe/austen/bourdieu.pdf 
9. Brown, J. (2006). De cuando lo privado se hace público o de como se construyen las políticas sobre sexualidady (no) reproducción. El caso de Mendoza, in Petracci \& Ramos (2006). La política pública de salud y los derechos sexuales y reproductivos en la Argentina. Aportes para comprender su historia. CEDES, UNFPA, Buenos Aires, Argentina. Available at:

https://repositorio.cedes.org/bitstream/123456789/3955/1/5213.pdf

10. Calero, A. (2018). Juventud y desigualdad multidimensional. El caso de Argentina 2004-2014 en el contexto latinoamericano. Laboratorio, 18(28), Primer semestre de 2018. Available at: https://publicaciones.sociales.uba.ar/index.php/lavboratorio/article/view/1643

11. Checa, S. (2003). Aproximaciones a la problemática de la sexualidad adolescente. In S. Checa, Susana (Comp.) Género, sexualidad y derechos reproductivos en la adolescencia. Paidós Tramas Sociales. ISBN 9789501290837

12. Dukuen, J. (2018). Habitus y dominación en la antropología de Pierre Bourdieu. Una crítica desde la femenología de Maurice Merleau-Ponty. Editorial Biblos. ISBN978-987-691-683-7

13. Duschatzky \& Corea (2007). Chicos en banda. Los caminos de la subjetividad en el declive de las instituciones. Paidós Tramas Sociales. Available at: https://ispp7-sgo.infd.edu.ar/sitio/upload/P.E-2_An_oResumen_de_chicos_en_banda_Psicologia_y_Cultura_del_sujeto_que_aprende_II.pdf

14. Faur, E. (2003). ¿Escrito en el cuerpo? Género y derechos humanos en la adolescencia, in S. Checa (Comp.) Género, sexualidad y derechos reproductivos en la adolescencia. Paidós Tramas Sociales. Available at: https://www.researchgate.net/profile/EleonorFaur/publication/327796708 Escrito en el cuerpo Genero y derechos humanos en la Adolescencia/li nks/5ba4e28492851ca9ed1b17a7/Escrito-en-el-cuerpo-Genero-y-derechos-humanos-en-laAdolescencia.pdf

15. Gogna M. (Coord.) (2005). Embarazo y maternidad en la adolescencia. Estereotipos, evidencias y propuestas para políticas públicas. Ministerio de Salud, Argentina: UNICEF-CEDES. Available at: https://fundacionapego.org/apc-aa-files/457374617475746f7345737472756374/embarazo_y_maternidadadolescente4.pdf

16. Kessler G. (Comp.) (2016) La sociedad Argentina hoy. Radiografía de una nueva estructura, Siglo XXI Editores. ISBN: 978-987-629-626-7

17. Lahire, B. (2005). De la teoría del habitus a una sociología psicológica. In B. Lahire (Dir.) El trabajo sociológico de Pierre Bourdieu. Deudas y críticas. Siglo XXI editores. Available at: https://www.redalyc.org/pdf/2831/283121840004.pdf

18. Mancini \& Wang (2003). Prácticas anticonceptivas entre las mujeres jóvenes. In M. Margulis. Juventud, cultura, sexualidad. La dimensión cultural en la afectividad y la sexualidad de los jóvenes de Buenos Aires. Editorial Biblos. ISBN: 9507863656. 
19. Mansione, I.; Pallma, S.; Steiman, A. (2012). Embarazo, maternidad y paternidad adolescentes. Ed. CICCUS.

20. Margulis, M.; Cecconi, S.; Ferraudi Curto, M. C. (2003). Juventud, cultura, sexualidad. La dimensión cultural en la afectividad y la sexualidad de los jóvenes de Buenos Aires. Editorial Biblos; Buenos Aires. ISBN: 9507863656.

21. Martinez, A. (2007). Pierre Bourdieu: razones y lecciones de una práctica sociológica (del estructuralismo genético a la sociología reflexiva). Ediciones Manantial. ISBN 9875001007.

22. Merklen, D. (2010). Pobres ciudadanos. Las clases populares en la era democrática (Argentina 19832003). Ed. Gorla. Available at:

https://perio.unlp.edu.ar/ojs/index.php/question/article/download/353/285/1300

23. Minujin, A. (Ed.) (1993). Desigualdad y exclusión. Desafios para la política social Argentina de fin de siglo. UNICEF-LOSADA.

24. Mohajan, Haradhan Kumar (2018). Qualitative Research Methodology in Social Sciences and Related Subjects, Journal of Economic Development, Environment and People, Vol-7, Issue 01, 2018, pp. 23-48. Available at: https://mpra.ub.uni-muenchen.de/85654/1/MPRA paper 85654.pdf

25. Molina, G. (2013). Género y sexualidades entre estudiantes secundarios. Un estudio etnográfico en escuelas cordobesas. IDES, Miño y Davila. Available:

https://rdu.unc.edu.ar/bitstream/handle/11086/18699/G_nero_y_sexualidades_imprenta_FINAL.pdf?seque $\underline{\text { nce }=1 \& \text { is Allowed }=\mathrm{y}}$

26. Morgan \& Spanish (1984). Focus Groups: A New Tool for Qualitative Research. Qualitative Sociology. 7(3), Fall 1984. Available at:

https://d1wqtxts1xzle7.cloudfront.net/49924430/Focus_groups_A_new tool_for_qualitative_2016102717611-1ww6b40-with-cover-page-v2.pdf?Expires=1642797593\&Signature=BbXMZufnM6ArA5DsrSMbb rofYDPLhX0xoNNpoS7Q7s4JUxhOkaJAmCMqOC9aYEn czawha9s6EWZ103SMj7czdM7HVE 6eYCZhTGFO7RQjgofaGcan275Rdv6DzMRrKBESjNWEcORTO3qkCHYJvWhyGiVGgHLuWWKQsO Qc0IdlptHEq6pVSSOpaGmh75g9dqd1 co3GkQfUYnoDDNss-

QLuIH7yCoCmuCAeohw3P6b2YBbrgj6PgOHtcI87NpTEf9SrfyOOT3CMIkBIk06UMtbWjupIQxPGZSYUIjnZfLDtmsckp34RdO0Wu2-RKVld97dA3YL3rUKySnpy1yPeQA_\&Key-Pair$\underline{\mathrm{Id}=\mathrm{APKAJLOHF} 5 \mathrm{GGSLRBV4ZA}}$

27. Nascimento L.; Vignuda de Souza T.; dos Santos Oliveira, I.; Montenegro Medeiros de Moraes, L.; Burla de Aguiar, R.; Faria da Silva, L. (2018). Theoretical saturation in qualitative research: an experience report in interview with schoolchildren. Rev Bras Enferm [Internet]. 2018;71(1):228-33. DOI: http://dx.doi.org/10.1590/0034-7167-2016-0616.

28. PAHO/UNFPA/UNICEF (2017). Pan American Health Organization, United Nations Population Fund and United Nations Children's Fund (2017). Accelerating progress toward the reduction of adolescent 
pregnancy in Latin America and the Caribbean. Report of a technical consultation (Washington, D.C., USA, August 29-30, 2016). Available at: https://iris.paho.org/handle/10665.2/34493

29. Pantelides \& Binstock (2007). La fecundidad adolescente en la Argentina al comienzo del Siglo XXI. Argentinean Journal of Sociology, 5 - 9. Available at: https://www.redalyc.org/pdf/269/26950903.pdf

30. Pérez \& Busso (2018). Juventudes, educación y trabajo. In Piovani \& Salvia (Coord.). La Argentina en el Siglo XXI. Cómo somos, vivimos y convivimos en una sociedad desigual, Siglo XXI Ed. Available at: http://biblioteca.clacso.edu.ar/clacso/se/20190704041228/La_Argentina_en_el_siglo_XXI.pdf

31. Piovani \& Salvia (2018). La Argentina en el Siglo XXI. Cómo somos, vivimos y convivimos en una sociedad desigual. Siglo XXI Ed. Available at:

http://biblioteca.clacso.edu.ar/clacso/se/20190704041228/La_Argentina_en_el_siglo_XXI.pdf

32. Piovani, J. (2018). La entrevista en profundidad. In Marradi et al. (2018). Manual de Metodología de las Ciencias Sociales. Siglo XXI Ed. Available at: https:/www.scribd.com/document/492141649/Piovani2018-La-entrevista-en-profundidad

33. Plan ENIA (2019). Ministry of Education, Culture, Science and Technology and Ministry of Health and Social Development and UNICEF: National Plan for the Prevention of Unintentional Pregnancy in Adolescence (Plan Nacional de Prevención del Embarazo no Intencional en la Adolescencia - Plan ENIA), Buenos Aires. Available at: https://www.argentina.gob.ar/planenia

34. Rodríguez Vignoli, J.; Di Cesare, M.; Páez, K. (2017). Reproducción temprana. Diferencias entre grandes regiones del mundo al inicio y al final de la adolescencia. ECLAC-UNFPA. Available at: https://www.cepal.org/es/publicaciones/41609-reproduccion-temprana-diferencias-grandes-regionesmundo-al-inicio-al-final-la

35. Rostagnol, S. (2016). Aborto voluntario y relaciones de género: políticas del cuerpo y de la reproducción. Universidad de la República, Uruguay. https://hdl.handle.net/20.500.12008/11003

36. Saavedra, L. (2018). Jóvenes de hogares urbanos de Argentina. Condiciones laborales y educativas en perspectiva comparada con la década del 90. Lavboratorio, 18(28). Available at: https://publicaciones.sociales.uba.ar/index.php/lavboratorio/article/view/2626

37. Salvia \& Tuñón (2006). Jóvenes excluidos y politicas fallidas de inserción laboral e inclusión social, Journal Acceso Directo, vol. 1, pp. 89-115. Available at: https://www.aacademica.org/ianina.tunon/16.pdf

38. Scott, J. W. (1996). El género: una categoría útil para el análisis histórico. In Marta Lamas Comp. El género: la construcción cultural de la diferencia sexual. PUEG. Available at:

https://www.fundacionhenrydunant.org/images/stories/biblioteca/Genero-MujerDesarrollo/El_Genero_Una_Categoria_Util para_el_Analisis_Historico.pdf

39. Svampa, M. (2005). La sociedad excluyente: la Argentina bajo el signo del neoliberalismo, Taurus. Available at: https://desarrollomedellin.files.wordpress.com/2017/04/svampa-maristella-2005-la-sociedadexcluyente-cap-1.pdf 
40. Tenti Fanfani, E. (1993). Cuestiones de exclusión social y política. In A. Minujin Ed. Desigualdad y exclusión. Desafíos para la política social Argentina de fin de siglo. UNICEF-LOSADA. ISBN: 9500371715.

41. Tuñón, I. (2018). Inequidades en la niñez y la adolescencia. In Piovani \& Salvia Coord. La Argentina en el Siglo XXI. Cómo somos, vivimos y convivimos en una sociedad desigual. Siglo XXI Ed. Available at: https://www.jstor.org/stable/pdf/j.ctvtxw2b7.20.pdf

42. UNFPA Argentina (United Nations Population Fund - Argentina) (2017). Estrategia conjunta de salud sexual, salud reproductiva y educación sexual en la adolescencia. Available at:

https://argentina.unfpa.org/es/publications/estrategia-conjunta-de-salud-sexual-salud-reproductiva-yeducaci $\% \mathrm{C} 3 \% \mathrm{~B} 3$ n-sexual-en-la

43. UNFPA Argentina/Ministerio de Salud y Desarrollo Social/Ministerio de Educación, Cultura, Ciencia y Tecnología (2019). El embarazo y la maternidad en la adolescencia en la Argentina. Datos y hallazgos para orientar líneas de acción. Available at:

https://www.argentina.gob.ar/sites/default/files/dt.5_el_embarazo_y_la_maternidad en_la_adolescencia.pd $\underline{\mathrm{f}}$

44. UNICEF/MSDS - Ministerio de Salud y Desarrollo Social (2019). Estadísticas de los hechos vitales de la población adolescente en la Argentina. Available at: https://www.unicef.org/argentina/informes/estadisticas-poblacion-adolescente-argentina

45. Wacquant, Loïc (2016). A concise genealogy and anatomy of habitus, The Sociological Review, Vol. 64, 64-72 (2016) DOI: https://doi.org/10.1111/1467-954X.12356

46. Wacquant, Loïc \& Aksu Akçaoğlu (2017). Practice and symbolic power in Bourdieu: The view from Berkeley, Journal of Classical Sociology, 2017, Vol. 17(1) 55-69. DOI:

https://doi.org/10.1177/1468795X16682145 